\title{
Customer Satisfaction on Internet Service Providers in Albania
}

\author{
Ana Buhaljoti, \\ Faculty of Economics, University of Tirana, Albania
}

Doi:10.19044/esj.2019.v15n28p235 URL:http://dx.doi.org/10.19044/esj.2019.v15n28p235

\begin{abstract}
The internet access in Albania has been growing steadily over the past decade, enhancing competitiveness and sustaining economic growth. Internet service providers (ISPs) have been raising significantly and competition is increasing. Thus, it is relevant to understand why customers stay with a particular service provider. The study sought to investigate the factors influencing customer satisfaction towards Internet Service Providers in Albania. Primary data were collected from 430 subscribers of ISPs by using a face to face survey methodology. The SERVPERF model was employed to identify the factors influencing internet services access. Results show that customer satisfaction is highly influenced by the Quality of the Service as the most important determinant of perceived service value which can enhance satisfaction in customer's opinion. The study implicates the marketing professionals in the telecommunications industry who are responsible for designing marketing strategies to foster competition and increase market share. The practical approach of the study involves an analysis of consumer perceptions in this market and strategic recommendations for ISPs.
\end{abstract}

Keywords: Satisfaction, Service quality, SERVQUAL, SERVPERF, Loyalty, Internet Service Providers (ISP), Telecommunication, Albania

\section{Introduction}

Internet is enhancing development in Albania as it increases the efficiency and competitiveness of the country in the global economy. It enables better delivery of health and education services and creates new sources of income and employment. Reforms in the telecommunication sector carried out between 1997 and 1998 contributed immensely towards the transformation of telecommunication services in Albania. The reforms were designed to introduce privatization, liberalization and competition into the telecommunication industry. 
Due to the Internet market liberalization, internet providers have rapidly increased in Albania. Internet Service Providers accelerated the modernization and the expansion of the industry as well as enhanced customer satisfaction through improving the service quality and increasing the efficiency of the sector.

Albania has an internet penetration level of $62 \%$ which is higher than the world average $46.5 \%$, but lower than the European Union where online penetration has exceeded $79 \%$. The country with the highest percentage of internet usage is the US with $88 \%$ (World Insta 2016).

The reason for growth of internet customers is aligned to the global trend of rapid growth of internet usage, market liberalization and a positive pressure exerted by government for electronic procurement, tax payments and other fiscal facilities through the Internet positively pressured the rise in demand for Internet service in Albania.

According to Electronic and Postal Communications Authority the number of subscribers to fixed broadband networks amounted 143 thousand. (AKEP 2016) The major provider is Albtelecom who owns $40 \%$ of retail fixed broadband market while among the alternative fixed operators, ABCom has the largest number of broadband connections with $21 \%$ market share. Although the number of Internet access service providers is large (25 active local operators), the four largest operators own $84 \%$ of this market (AKEP 2016).

As the telecommunication industry moves from a regulated market to a competitive environment, many organisations are concerned in increasing customer satisfaction. The satisfaction of customers with their Internet provider indicate the attitudinal bonding or contractual relationship with the supplier (Gerpott et al., 2001). It has been shown that customer satisfaction directly affects companies' market share, which leads to improved profits, positive recommendation and lower marketing expenditures (Heskett et al., 1997). Thus, the study helps service providers to come to grips the key factors that affect customer's satisfaction and make them repurchase.

\section{Literature Review}

\section{Customer satisfaction}

Customer satisfaction is considered as the best studied concept in marketing literature (Liu \& Jang, 2009). It is a direct response to consumption (Munusamy \& Chelliah, 2011). Satisfaction is the customers' evaluation of a product/service in terms of whether it has met their needs and expectations (Zeithaml \& Bitner 2003). Anderson and Fornell (1993) view satisfaction as customer's total consumption experience with a product or service over multiple transactions (Anderson and Fornell 1993). 
A definition of satisfaction is "customer response after service performance evaluation to expected standards" (Jack and Powers, 2013). Expectations are influenced by previous experiences with the service but also what others have said about the brand. If the customer feels satisfied, then the long-term relationship with the organization can be established (Munusamy \& Chelliah, 2011).

Liu \& Yang (2009) argue that different scholars have developed different theories of customer satisfaction, including expectation-rejection theory and three-factor theory.

The expectation-rejection theory is widely accepted (Liu \& Jang, 2009). According to Reisig and Stroshine Chandek (2001), this theory is summarized in a four-stage process. First, the customer formulates expectations for a product. The customer can imagine performance based on his product knowledge. Expectations may be normative, as customer' judgement of the expected performance. Second, customer value product performance. Third, a comparison is made between the impression of the customer and his initial expectations. Finally, the customer's decision on the product is taken. (Reisig and Stroshine Chandek, 2001)

According to Oliver (2010) customer satisfaction is the result of a comparison between expectations and perceived performance. When the perceived performance is above expectations, then the customer is satisfied. Conversely, if perceived performance will be under expectations, the customer is dissatisfied. This means that the customer can judge the performance of the product as better or worse, or equal to expectations. Compatibility between customer's perception of the product and its initial expectations leads to satisfaction. The perception of performance is seen as the attribute of satisfaction measurement. (Oliver, 2010)

The three factor theory includes basic factors, emotional factors and performance factors (Füller \& Matzler, 2008). Basic factors refer to minimum customer requirements. If the minimum requirements are not met, the customer will be dissatisfied. The emotional factor can increase customer satisfaction. This means that the emotional factor has a positive impact on pleasure. The performance factor is a direct reflection of perceived performance. The three-factor theory has been tested and proven by empirical researchers such as Liu and Yang, 2009.

According to Füller and Matzler (2008), core factors are considered the most basic condition for satisfaction. Performance factors are competitive and have a direct impact on the needs and desires of the customer. Emotional factors are termed as surprise factors for consumers, implying that this surprise can increase satisfaction.

Customer satisfaction can be viewed as a strong predictor of customer loyalty and has been identified as an antecedent to customer loyalty (Anderson \& 
Srinivasan 2003). Hussain, Al Nasser \& Hussain (2015) emphasizes that retaining existing customers is more important than attracting new customers. Internet service providers try to please customers to survive the intense competition.

Studies in this field indicate that the quality of the internet connection is key driver to customer satisfaction. According to Vassileva and Balloni (2014) the service quality is the most studied area of services literature leading to customer relationship. It is closely related to costs, profitability, customer satisfaction and customer retention (Vassileva and Balloni 2014). The origins of the service quality study occur in early theoretical works from Nordic School (Grönroos, 1983; Lehtinen and Lehtinen, 1982). Most descriptions of quality are customer centred and according to Parasuraman et al., (1988) perceived quality is a task of customer satisfaction (Vassileva and Balloni, 2014).

The complex issue of access quality is primarily narrowed down to objectively measured or subjectively experienced download and upload transmission speeds of Internet connections (Quach et al., 2016; Thaichon et al., 2014;). Authors review the quality parameters of Internet access services. and suggest that the bandwidth of Internet connections tend to have significant positive and negative, respectively, effects on satisfaction of customers with the internet provider (Giovanis et al., 2014; Grzybowski et al., 2018). The connection speed is an extraordinarily important quality feature. The testing instruments enable users to measure the transmission rates they actually get from their Internet connection supplier (Elkins, 2018).

Service quality assessment with internet services depends directly on monitoring customer interaction with the provided service.

Khatibi, Ismail and Thyagarajan (2002) studied the relationship between quality perceptions of perceived related to price and customer satisfaction in the Malaysian telecommunication industry. The study discovers that there is a significant correlation between customer satisfaction and service quality. Wang, Lo and Yang (2004) further investigated the dynamic relationships between service quality, customer value and customer satisfaction and their influence on customer behaviour in China's mobile phone market. The results indicate that network quality is one of the most important drivers of overall customers' perceived value derived from service quality, customer value, and customer satisfaction.

Customers perceive the failure to supply the agreed connection bandwidth as a (psychological) "loss" (Chuang et al., 2012). More frequent losses contribute to a lower experienced value or quality of a service and result in decreasing customer loyalty to the Internet provider. (Stocker and Whalley, 2018) 
According to Athanassopoulos and Iliakopoulos (2003), who researched customer's satisfaction of the residential customers of a major European telecommunication company, the antecedents of customer satisfaction in the telecommunication industry can be assessed through the performance of service providers.

\section{Factors affecting service quality}

Satisfaction is a holistic feeling toward a product or service and results from the evaluation of each aspect of an offering (Zeithaml, Berry \& Parasuraman 1996).

There are several factors that can be used to measure the service quality. SERVQUAL tool was developed to be used in the marketing industry. It is used to perform gap analysis which is based on the difference between perceptions and expectations of quality of services. The tool can be used in wide range of services. According to Parasuraman et al., (1985), SERVQUAL is an instrument with a good validity and reliability and uncovers the organization's service strengths and weaknesses in terms of quality.

The original SERVQUAL model consisted of 10 general dimensions: 1) tangibles, 2) reliability, 3) responsiveness, 4) competence, 5) courtesy, 6) credibility, 7) security, 8) access, 9) communication, and 10) understanding (Parasuraman et.al., 1988). Further study by Parasuraman (1988, 1990) revealed correlated dimensions, reducing the number of dimensions from 10 to 5. The first factor is the tangibility which is based on physical facilities and personnel appearance, second is reliability as the ability to perform the services accurately and dependable, third factor is responsiveness, which is the willingness to help customers and provide prompt services, fourth factor is assurance as the knowledge and courtesy of employees and ability to build trust and confidence to customers and fifth is empathy which is caring individual attention to customers. (Parasuraman et al., 1988).

In order to examine the applicability of SERVQUAL model in the Telecommunication industry, several empirical studies have been conducted by adapting SERVQUAL instrument. Cronin and Taylor (1992) developed an alternative measurement tool, SERVPERF. This model takes a quite different approach than the SERVQUAL to eliminate the expectations problems. It was proved to have better applicability in the examined industry. (Cronin and Taylor, 1992). To support this idea, Lee, Lee and Yoo (2000 developed research focusing on the determinants of perceived service quality. The finding of their study indicate that the performance-based measures of service quality (SERVPERF) work better and detect more of the variations in service quality.

Accordingly, Wang, Lo and Yang (2004) used the measurement model to measure customers' perceived service quality in China's mobile phone 
market. They agreed with a number of researchers (Cronin \& Taylor 1992; Dabholkar, Thorpe \& Rentz 2000; Oliver 1993) that combining expectations and perceptions into a single measure outperforms the SERVQUAL scale in terms of both reliability and validity. In terms of 'performance' Wang, Lo and Yang (2004) used network quality because it was one of the most important factors determining overall quality in the telecommunication market. Thus, instead of having only the original five SERVQUAL dimensions of tangibility, reliability, responsiveness, assurance, and empathy (Parasuraman, Berry \& Zeithaml 1991), Wang, Lo and Yang (2004) also included another antecedent factor, which is 'network quality' as a driver for customers' overall perceived quality evaluation in the mobile phone market. The results of Wang, Lo, Yang's (2004) suggest that customer- perceived service quality is influenced by six underlying factors tangibility, reliability, responsiveness, assurance, empathy, and network quality.

For the reasons discussed above, the measurement of service quality in this study will be based on the SERVPERF model as it would have managerial interest to test the applicability of that model to the Internet Industry in Albania

\section{Methodology}

The research aims to explore the factors influencing customer satisfaction with Internet Service Providers in Albania. The primary data collected tend to evaluate customers as rational. The survey questionnaire consisted of questions on a Likert scale of 1 to 7 (where 1 is 'Strongly disagree' and 7 is 'Strongly agree') and determined approaches to choosing a high-speed internet service provider, experience with high-speed internet, future intention towards service providers; and demographic questions. The survey was conducted face to face and increased the level of trust and cooperation between interviewer and respondent. (Sekaran 2003)

The target population of the study are internet users aged 16-55 who have home-based Internet connections. According to Electronic and Postal Communications Authority the number of subscribers to fixed broadband networks at the end of 2016 was 242,870 inhabitants. The population sample is 400 individuals. The sampling method is probability in proportion to size. The probability of an individual to be selected is proportional to the size of the cluster to which he belongs, giving greater clusters greater probability of selection and small groupings the lower probability.

According to AKEP, the number of subscribers with broadband access from the fixed network has an inappropriate distribution by regions Tirana 49\%, Durrës 10.2\%, Shkodra 6.85\%, Vlora 6.6\%, Korca 6.2\%, Fier 6.1\%, Elbasan $4.1 \%$ as shown in Table 1. 
Table 1. The national distribution of the sample

\begin{tabular}{|l|l|l|l|}
\hline Region & $\begin{array}{l}\text { Number of subscribers } \\
\text { with Broadband access }\end{array}$ & Index by region size & Sample \\
\hline Vlorë & 16,149 & 0.07 & 27 \\
\hline Tiranë & 118,954 & 0.49 & 196 \\
\hline Shkodër & 16,647 & 0.07 & 27 \\
\hline Lezhë & 8,253 & 0.03 & 14 \\
\hline Kukës & 2,454 & 0.01 & 4 \\
\hline Korçë & 15,134 & 0.06 & 25 \\
\hline Fier & 15,047 & 0.06 & 25 \\
\hline Gjirokastër & 5,252 & 0.02 & 9 \\
\hline Elbasan & 10,590 & 0.04 & 17 \\
\hline Durrës & 24,803 & 0.10 & 41 \\
\hline Dibër & 3,236 & 0.01 & 5 \\
\hline Berat & 6,309 & 0.03 & 10 \\
\hline Total & 242,828 & 1.00 & 400 \\
\hline
\end{tabular}

Respondents are selected randomly. Every third person in the main city centers is selected for interview. This allows all members of the targeted population to have an equal chance of being included in the sample. The randomly selected respondents had to meet the criteria of using the internet service at home and fall in the users age group 16-55 years old.

\section{Analysis}

The findings of this study derived from a well-structured questionnaire consisted of questions on a Likert scale of 1 to 7 (where 1 is 'Strongly disagree' and 7 is 'Strongly agree'). The collected data was analyzed via Statistical Package for the Social Sciences SPSS.21 and the main data analysis includes: descriptive analysis, factor analysis, correlation analysis with correlation coefficient (Pearson), and multiple regression analysis.

The distribution and profile of the 430 respondents who participated in this research is presented in table 2 .

Table 2. Number of respondents by regions

\begin{tabular}{|ll|c|c|c|c|}
\hline & Frequency & Percent & $\begin{array}{c}\text { Valid } \\
\text { Percent }\end{array}$ & $\begin{array}{c}\text { Cumulative } \\
\text { Percent }\end{array}$ \\
\hline Valid & Berat & 6 & 1.4 & 1.4 & 1.4 \\
& Diber & 4 & .9 & .9 & 2.3 \\
Durres & 39 & 9.1 & 9.1 & 11.4 \\
Elbasan & 24 & 5.6 & 5.6 & 17.0 \\
Fier & 25 & 5.8 & 5.8 & 22.8 \\
Gjirokaster & 8 & 1.9 & 1.9 & 24.7 \\
Korce & 43 & 10.0 & 10.0 & 34.7 \\
Kukes & 4 & .9 & .9 & 35.6 \\
Lezhe & 11 & 2.6 & 2.6 & 38.1 \\
Shkoder & 32 & 7.4 & 7.4 & 45.6 \\
Tirane & 190 & 44.2 & 44.2 & 89.8 \\
Vlore & 44 & 10.2 & 10.2 & 100.0 \\
Total & 430 & 100.0 & 100.0 & \\
\hline
\end{tabular}


Figure 1. Age

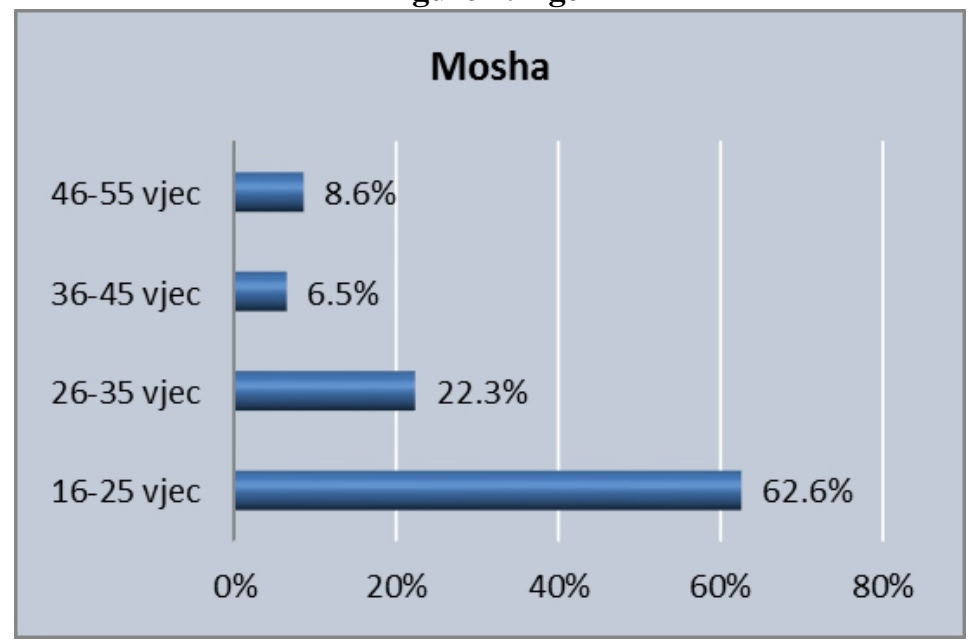

The group of 430 respondents includes internet users from the age of 16 to 55 . Most of the respondents $(62.6 \%)$ belong to the age group of 16-25 years as the broadest segment with access on internet. In terms of education, $51.6 \%$ of respondents have completed university, representing the largest number of Internet users.

Figure 2. Internet Service Provider of connected households

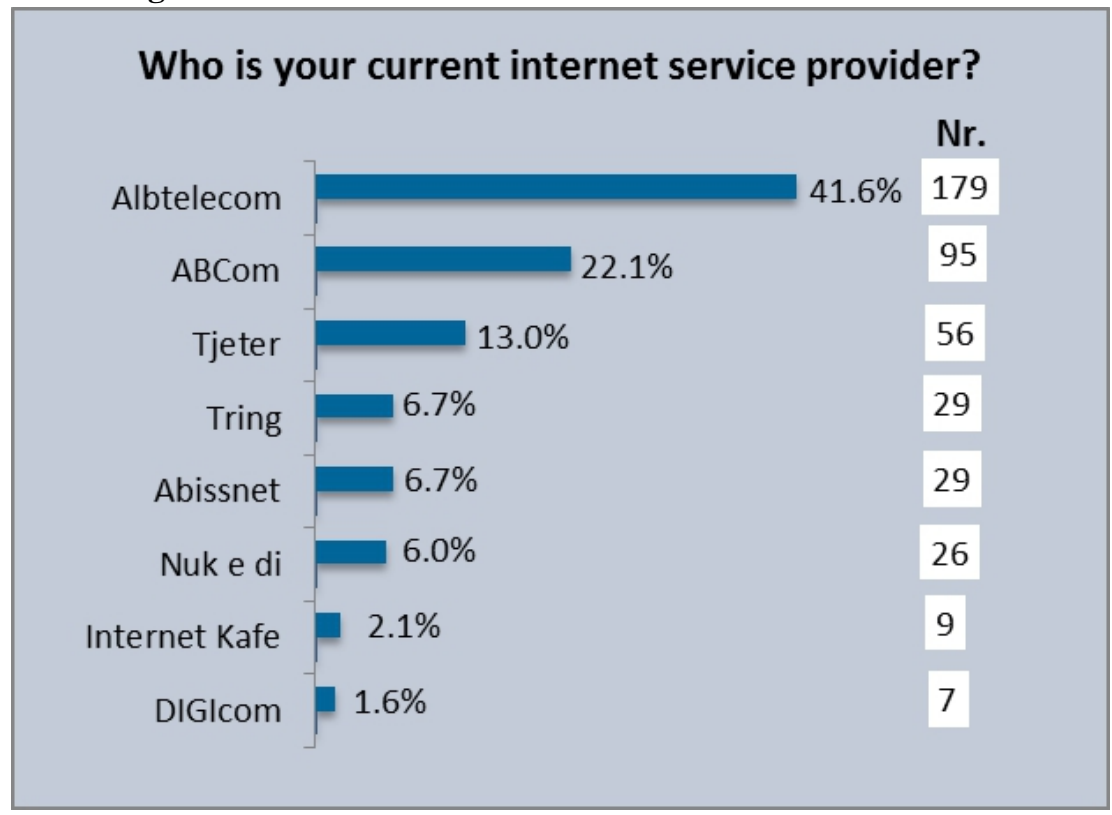

Most of the respondents are connected to the market leader Albtelecom which has the advantage of national coverage and infrastructure ownership. Respondents use internet access at home for three main reasons 
communication (to communicate, for e-mail), education (to read / inform) and entertainment (for video / music, to download movies / books, to play).

Figure 3. Internet usage rate

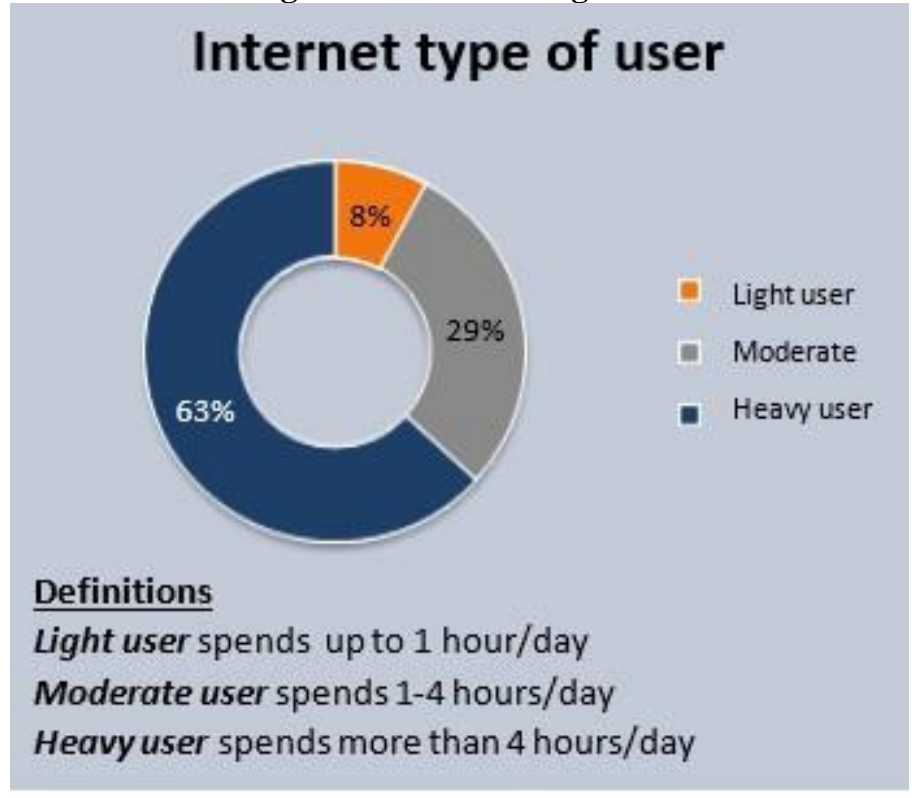

Respondents were asked about the frequency of using internet and the average hours they spend every time they hook to the internet. Monthly hours spend on internet were calculated per user by multiplying the frequency of usage for each access point with the average hours spend when accessing the internet in the specific access point. Most of the respondents $(63 \%)$ have high usage rates, spending over 4 hours a day on the Internet.

\section{Factors Affecting Customer Satisfaction with ISPs}

Table 3 shows the factorial analysis for Customer Satisfaction. The values of the matrix of the coefficients for the complex variable "Customer Satisfaction" are determined with the PCA method and the Promax rotation method with Kaiser Normalization and serves to predict consumer behavior. There are 3 Eigen values greater than 1 and others are less than 1 . This indicates that three factors can be determined from this set of questions that forms the complex variable "Customer Satisfaction".

Table 3. Factorial Analysis for Customer Satisfaction

\begin{tabular}{|c|c|c|c|c|}
\hline \multirow[b]{2}{*}{ Variable } & \multicolumn{4}{|c|}{ FACTOR } \\
\hline & $-\underset{\tilde{E}}{\stackrel{E}{\tilde{E}}} \lambda$ & $\sim \stackrel{\overrightarrow{0}}{\stackrel{\overrightarrow{b 0}}{\Xi}}$ & 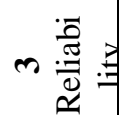 & 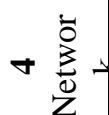 \\
\hline $\begin{array}{l}\text { PR 1.1 The service provider has up-to-date } \\
\text { equipment }\end{array}$ & -0.014 & 0.194 & 0.065 & 0.087 \\
\hline PR1.2 The service provider's employees are & -0.047 & 0.305 & -0.053 & 0.021 \\
\hline
\end{tabular}




\begin{tabular}{|l|c|c|c|c|}
\hline well dressed and appear neat & & & & \\
\hline $\begin{array}{l}\text { PR1.3 The shops of the service provider are } \\
\text { clean and well maintained }\end{array}$ & -0.001 & 0.303 & -0.036 & -0.046 \\
\hline $\begin{array}{l}\text { B1.1 The service provider delivers its services at } \\
\text { the timed promised }\end{array}$ & 0.032 & 0.149 & 0.130 & 0.000 \\
\hline $\begin{array}{l}\text { B1.2 The service provider always performs the } \\
\text { service right the first time }\end{array}$ & -0.063 & -0.064 & 0.378 & -0.030 \\
\hline B1.3 The service provider is dependable & 0.029 & 0.091 & 0.172 & 0.056 \\
\hline $\begin{array}{l}\text { P1.1 When I have a problem, the employees } \\
\text { offer the right solution }\end{array}$ & 0.052 & 0.055 & 0.217 & 0.013 \\
\hline $\begin{array}{l}\text { P1.2 When the service provider promises to do } \\
\text { something, it does so }\end{array}$ & 0.088 & 0.022 & 0.202 & 0.005 \\
\hline P1.3 Employees give me prompt service & 0.070 & 0.045 & 0.174 & 0.036 \\
\hline $\begin{array}{l}\text { S1.1 Employees are well-mannered and patient } \\
\text { with customers }\end{array}$ & 0.146 & 0.118 & 0.018 & -0.103 \\
\hline $\begin{array}{l}\text { S1.2 Employees have the knowledge to answer } \\
\text { customers' questions }\end{array}$ & 0.160 & 0.107 & 0.018 & -0.093 \\
\hline S1.3 I feel safe with this service provider & 0.059 & 0.059 & 0.093 & 0.155 \\
\hline $\begin{array}{l}\text { E1.1 The service provider gives customers } \\
\text { individual attention }\end{array}$ & 0.231 & -0.089 & -0.036 & -0.020 \\
\hline $\begin{array}{l}\text { E1.2 The service provider has convenient } \\
\text { operating hours }\end{array}$ & 0.185 & -0.005 & -0.022 & -0.008 \\
\hline $\begin{array}{l}\text { E1.3 In case of a problem, the service provider } \\
\text { shows interest and security in solving it }\end{array}$ & $\mathbf{0 . 1 5 8}$ & -0.009 & 0.061 & 0.034 \\
\hline $\begin{array}{l}\text { E1.4 The customer service staff knows my } \\
\text { specific needs }\end{array}$ & $\mathbf{0 . 1 9 7}$ & -0.028 & -0.107 & 0.080 \\
\hline C1.1 The quality of the network is always stable & -0.013 & -0.007 & -0.008 & $\mathbf{0 . 4 2 6}$ \\
\hline $\begin{array}{l}\text { C1.2 The quality and strength of the network is } \\
\text { always excellent }\end{array}$ & -0.009 & -0.011 & -0.015 & $\mathbf{0 . 4 3 1}$ \\
\hline Eigenvalue & $\mathbf{8 . 5 4 1}$ & $\mathbf{1 . 4 9 9}$ & $\mathbf{1 . 1 3 7}$ & $\mathbf{1 . 0 7 4}$ \\
\hline \% of Variance & $\mathbf{4 7 . 4 4 7}$ & $\mathbf{8 . 3 2 6}$ & $\mathbf{6 . 3 1 4}$ & $\mathbf{5 . 9 6 7}$ \\
\hline
\end{tabular}

The first Factor with the Eigen value 8.541 covers $47.447 \% \%$ of the total variance. For this factor we have the highest coefficient values from the group of questions E 1.1 and E 1.4 that belongs to the independent variable Empathy. This factor will be named "Empathy".

The second factor with the Eigen value 1.499 covers $8.326 \% \%$ of the total variance. For this factor we have the largest coefficient values from the group of questions PR1.2 and PR1.3 that belongs to independent variable Tangibility. This factor will be named " Tangibility" as it is defined by independent variables of the same name.

The third factor with the Eigen value 1.137 covers $6.314 \%$ of the total variance. For this factor we have the highest values of coefficients from the group of questions B1.2 that belongs to the independent variables Reliability. This factor will be named "Reliability" as it is determined by independent variables of the same name. 
The third factor with the Eigen value 1.074 covers $5.967 \%$ of the total variance. For this factor we have the highest values of coefficients from the group of questions $\mathrm{C} 1.1$ and $\mathrm{C} 1.2$ that belongs to independent variable Network quality. This factor will be named " Network quality". From the matrix it can be seen that the other coefficients are small and can be neglected.

Table 4. Factor Correlation matrix

\begin{tabular}{|c|c|c|c|c|}
\hline Factor & Empathy & Tangibility & Reliability & $\begin{array}{c}\text { Network } \\
\text { quality }\end{array}$ \\
\hline Empathy & 1.000 & .674 & .706 & .573 \\
Tangibility & .674 & 1.000 & .636 & .456 \\
Reliability & .706 & .636 & 1.000 & .560 \\
Network & .573 & .456 & .560 & 1.000 \\
quality & & & & \\
\hline
\end{tabular}

Table 5 presents the results of the factorial analysis for the reliability of the three factors of customer choice. The overall Cronbach Alfa coefficient is $0.925>0.8$ which is the very reliable level according to the Alpha Test Table.

Table 5. Reliability of composite variables

\begin{tabular}{|l|c|c|}
\hline \multicolumn{1}{|c|}{ Variable } & $\begin{array}{c}\text { Correlation } \\
\text { Coeficient }\end{array}$ & $\begin{array}{c}\text { Cronbach } \\
\text { Alpha by } \\
\text { eliminating } \\
\text { variable }\end{array}$ \\
\hline PR1.2 The service provider's employees are well dressed and appear neat & 0.420 & 0.927 \\
\hline PR1.3 The shops of the service provider are clean and well maintained & 0.517 & 0.924 \\
\hline B1.2 The service provider always performs the service right the first time & 0.262 & 0.932 \\
\hline S1.1 Employees are well-mannered and patient with customers & 0.655 & 0.921 \\
\hline S1.2 Employees have the knowledge to answer customers' questions & 0.705 & 0.920 \\
\hline E1.1 The service provider gives customers individual attention & 0.531 & 0.924 \\
\hline E1.2 The service provider has convenient operating hours & 0.614 & 0.921 \\
\hline $\begin{array}{l}\text { E1.3 In case of a problem, the service provider shows interest and security in } \\
\text { solving it }\end{array}$ & 0.734 & 0.919 \\
\hline E1.4 The customer service staff knows my specific needs & 0.581 & 0.922 \\
\hline C1.1 The quality of the network is always stable & 0.606 & 0.922 \\
\hline C1.2 The quality and strength of the network is always excellent & 0.609 & 0.922 \\
\hline
\end{tabular}

Table 5 shows that correlation coefficients for some questions are low (less than 0.5). The coefficient of question B1.2 is too low (0.262) and this question will be excluded.The exclusion of each of the questions does not affect the increase in the value of Cronbach Alfa. The Cronbach Alfa coefficient continues to represent a high reliable level $(>0.8)$. Therefore, these factors affect customer satisfaction.

\section{Pearson's correlation coefficient}

Pearson's correlation coefficient (Pearson's r) was used to examine the 
relationships among the variables. The value of the Pearson correlation ranges from -1 to 1 , If $r=-1$ there is a perfectly negative relationship, if $r=0$ there is no relationship, and if $\mathrm{r}=1$ there is a perfectly positive relationship. (Tabachnick \& Fidell 2007) The correlation analysis between independent variables and dependent variables is summarized in Table 6.

Table 6. Analysis of correlation between dependent and independent variables

\begin{tabular}{|c|c|c|c|c|}
\hline $\begin{array}{c}\text { Independent } \\
\text { variable }\end{array}$ & Dependent variable & $\begin{array}{c}\text { Pearson } \\
\text { Correlation }\end{array}$ & $\begin{array}{c}\text { Sig } \\
(1-t a i l e d)\end{array}$ & Level \\
\hline Tangibility PR & & 0.453 & 0.000 & 0.05 \\
\hline Reliability BS & & 0.515 & 0.000 & 0.05 \\
\hline Responsiveness P & & 0.596 & 0.000 & 0.05 \\
\hline Assurance S & Customer satisfaction -KK & 0.599 & 0.000 & 0.05 \\
\hline Empathy E & & 0.574 & 0.000 & 0.05 \\
\hline Network Quality C & & 0.506 & 0.000 & 0.05 \\
\hline
\end{tabular}

From the results can be concluded that:

- There is a weak correlation between Tangibility and Consumer Satisfaction, $\mathrm{r}=0.453, \mathrm{p}=0.000(\mathrm{p}<0.05)$.

- There is a medium correlation between Credibility and Consumer Satisfaction, $r=0.515, \mathrm{p}=0.000(\mathrm{p}<0.05)$.

- There is a Medium correlation between Responsiveness and Consumer Satisfaction, $r=0.596, p=0.000(p<0.05)$.

- There is a Medium correlation between Assurance and Consumer Satisfaction, $r=0.599, p=0.000(p<0.05)$.

- There is a Medium correlation between Empathy and Consumer Satisfaction, $\mathrm{r}=0.574, \mathrm{p}=0.000(\mathrm{p}<0.05)$.

- There is a Medium correlation between Network Quality and Consumer Satisfaction, $r=0.506, p=0.000(p<0.05)$.

Table 7. The Consumer Satisfaction Model - Model Summary ${ }^{\mathrm{d}}$

\begin{tabular}{|c|c|c|c|c|c|c|c|c|c|c|}
\hline \multirow[b]{2}{*}{ Model } & \multirow[b]{2}{*}{$\mathrm{R}$} & \multirow[b]{2}{*}{$\begin{array}{c}\mathrm{R} \\
\text { Square }\end{array}$} & \multirow[b]{2}{*}{$\begin{array}{l}\text { Adjusted } \\
\text { R Square }\end{array}$} & \multirow[b]{2}{*}{$\begin{array}{l}\text { Std. Error } \\
\text { of the } \\
\text { Estimate }\end{array}$} & \multicolumn{5}{|c|}{ Change Statistics } & \multirow[b]{2}{*}{$\begin{array}{l}\text { Durbin- } \\
\text { Watson }\end{array}$} \\
\hline & & & & & $\begin{array}{c}\mathrm{R} \\
\text { Square } \\
\text { Change }\end{array}$ & $\begin{array}{c}\mathrm{F} \\
\text { Change }\end{array}$ & $\begin{array}{c}\mathrm{df} \\
1\end{array}$ & df2 & $\begin{array}{c}\text { Sig. } \\
\text { F } \\
\text { Cha } \\
\text { nge }\end{array}$ & \\
\hline 1 & $.453^{\mathrm{a}}$ & .206 & .204 & 1.46009 & .206 & 107.351 & 1 & 415 & .000 & \\
\hline 2 & $.563^{\mathrm{b}}$ & .316 & .313 & 1.35592 & .111 & 67.213 & 1 & 414 & .000 & \\
\hline 3 & $.631^{\mathrm{c}}$ & .398 & .394 & 1.27394 & .082 & 56.000 & 1 & 413 & .000 & \\
\hline 4 & $.654^{\mathrm{d}}$ & 427 & .422 & 1.24429 & .029 & 20.915 & 1 & 412 & .000 & \\
\hline 5 & $.670^{\mathrm{e}}$ & .448 & .442 & 1.22261 & .021 & 15.743 & 1 & 411 & .000 & \\
\hline 6 & $.684^{\mathrm{f}}$ & .467 & .459 & 1.20292 & .019 & 14.566 & 1 & 410 & .000 & 1.876 \\
\hline
\end{tabular}

g. Depedent Variable: Satisfaction 
Multiple regression model

$\mathrm{y}=\beta_{0}+\beta_{1} \mathrm{x}_{\mathrm{i} 1}+\beta_{2} \mathrm{x}_{2}+\beta \mathrm{p} \mathrm{x}$ ip $+\varepsilon$

for the dependent variables Consumer choice is given below:

Model 1: $\mathrm{KK}=2.390+0.514 * \mathrm{PR}+\mathrm{eKK}$

Model 2: $\mathrm{KK}=1.041+0.296 * \mathrm{PR}+0.468 * \mathrm{~B}+\mathrm{eKK}$

Model 3: $\mathrm{KK}=0.912+0.184 * \mathrm{PR}+0.202 * \mathrm{~B}+0.411 * \mathrm{P}+\mathrm{eKK}$

Model 4: $\mathrm{KK}=0.550+0.088 * \mathrm{PR}+0.159 * \mathrm{~B}+0.272 * \mathrm{P}+0.338 * \mathrm{~S}+\mathrm{eKK}$

Model 5: $\mathrm{KK}=0.396+0.095 * \mathrm{PR}+0.134 * \mathrm{~B}+0.210 * \mathrm{P}+0.201 * \mathrm{~S}+0.252 * \mathrm{E}+\mathrm{eKK}$

Model6:KK=0.400+0.091*PR+0.112*B+0.176*P+0.192*S+0.204*E+0.151

$* \mathrm{C}+\mathrm{Ekk}$

Table 8. ANOVA for Customer Satisfaction

ANOVA $^{g}$

\begin{tabular}{|ll|r|r|r|r|r|r|}
\hline \multirow{2}{*}{ Model } & & \multicolumn{1}{c|}{$\begin{array}{c}\text { Sum of } \\
\text { Squares }\end{array}$} & df & Mean Square & F & Sig. & $F_{\mathrm{kr}}$ \\
\hline 1 & Regression & 228.859 & 1 & 228.859 & 107.351 & $.000 \mathrm{a}$ & 3.89 \\
& Residual & 884.724 & 415 & 2.132 & & & \\
& Total & 1113.583 & 416 & & & & \\
\hline 2 & Regression & 352.432 & 2 & 176.216 & 95.846 & $.000 \mathrm{~b}$ & 3.04 \\
& Residual & 761.151 & 414 & 1.839 & & & \\
& Total & 1113.583 & 416 & & & & \\
\hline 3 & Regression & 443.316 & 3 & 147.772 & 91.053 & $.000 \mathrm{c}$ & 2.65 \\
& Residual & 670.267 & 413 & 1.623 & & & \\
& Total & 1113.583 & 416 & & & & \\
\hline 4 & Regression & 475.698 & 4 & 118.925 & 76.812 & $.000 \mathrm{~d}$ & 2.42 \\
& Residual & 637.884 & 412 & 1.548 & & & \\
& Total & 1113.583 & 416 & & & & \\
\hline 5 & Regression & 499.231 & 5 & 99.846 & 66.797 & $.000 \mathrm{e}$ & 2.26 \\
& Residual & 614.352 & 411 & 1.495 & & & \\
& Total & 1113.583 & 416 & & & & \\
\hline 6 & Regression & 520.308 & 6 & 86.718 & 59.929 & $.000 \mathrm{f}$ & 2.14 \\
& Residual & 593.275 & 410 & 1.447 & & & \\
\hline
\end{tabular}

g. Dependent Variable: Satisfaction

Multiple regression analysis results obtained for the dependent variables Consumer Satisfaction and complex variables 1) Tangibility 2) Reliability 3) Responsiveness 4) Assurance 5) Empathy 6) Network Quality are presented in Table 9. 
Table 9. Multiple regression between complex variables and Consumer Satisfaction

\begin{tabular}{|c|c|c|c|c|c|}
\hline Variabël & $\begin{array}{c}\text { Standardised Coefficients } \\
\text { Beta }\end{array}$ & $\mathbf{t}$ & Sig. & $\mathbf{t k r}$ & $\begin{array}{c}\text { Correlations } \\
\text { Part }\end{array}$ \\
\hline (Constant) & & 1.404 & .161 & & \\
PR & .080 & 1.709 & .088 & & .091 \\
B & .092 & 1.814 & .070 & 1.943 & .112 \\
P & .172 & 2.829 & .015 & & .176 \\
S & .158 & 2.480 & .024 & & .192 \\
E & .174 & 3.194 & .009 & & .204 \\
C & .171 & 3.817 & .004 & & .151 \\
\hline
\end{tabular}

Consumer Satisfaction is expressed as follows:

Model 6: KK $=0.176 * \mathrm{P}+0.192 * \mathrm{~S}+0.204 * \mathrm{E}+0.151 * \mathrm{C}+\mathrm{eKK}$

Results show that four variables Responsiveness, Assurance, Empathy and Network Quality influence consumer satisfaction of Internet service providers in Albania.

\section{Conclusion and implications:}

The key question of this research was to identify the factors that influence customer satisfaction with ISPs in Albania. The literature review identified key factors influencing customers' satisfaction among ISPs which had to be tested in the Albanian market. The empirical results are based on a sample of 420 connected customers, who are representatives of the population of home internet users and implied that the satisfaction of the customer is mostly influenced by Responsiveness, Assurance, Empathy and Network Quality.

Service providers have to improve service quality, deliver superior value, and understand carefully behaviour intentions of customers if they want to create and maintain their competitive advantage.

Responsiveness positively affects customer satisfaction. Internet service providers have to consider that when responsiveness is combined with other factors like Security, Empathy, and Network Quality customer satisfaction enhances and is likely to affect customer loyalty.

Important implications for Internet service providers in terms of readiness are developing service strategies, training and motivating staff to show readiness to serve customers' needs and be available to provide persistent service at all times.

Assurance is another factor with positive impact on customer satisfaction. Knowledge and credibility of employees increases customer assurance and ensures customer satisfaction. Internet Service Providers should periodically carry out professional training programs for their employees regarding the services provided by the company and the Internet service facilities. This is crucial to staff serving and interacting with clients, such as sales, marketing, and technical support units. ISPs should ensure that their 
staff is prompt to respond and shows a willingness to cater the customers' needs.

Empathy of the front desk staff positively affects the overall perception of service quality and positively affects customer satisfaction. Customer satisfaction is based on their interaction with the staff. Companies that provide telecommunication services should be concerned about staff selection and training to strengthen customer-orientation and improve staff empathy.

Network quality is the most important factor to build customer satisfaction. Internet service providers should constantly monitor their internet strength and assess the quality of the network. Customers evaluate quality dimensions of purchased services with regard to the speed of Internet connections from the maximal bandwidth that suppliers commit in their customer contracts or from speed claims that they highlight in advertisements. A practical recommendation would be to invest in auto configuration system and allow immediate reconfiguration in case of damage occurrences to ensure signal stability. Internet service providers should note that improvements in quality of service will increase customer satisfaction.

Research findings show that customer satisfaction is not affected by the level of tangibility of the service. The tangibility of a service comprises of physical devices, equipment and contemporary appearance of a business i.e. service employees' appearance and dress code or the provider up-to-date service equipment. Customers seem mostly concerned about the quality of the internet, as an intangible component. However, the speed and quality of the internet signal can be assessed by consumers. Internet users are able to show how fast, slow and reliable the signal is when using the internet. Internet companies must ensure that the internet speed comply to the advertised bandwidth.

Although this research show that service tangibility does not affect customer satisfaction, visual service elements can't be overlooked by Internet providers as they have an impact on customer image.

In order to maintain a competitive advantage and enhance the degree of customer satisfaction, the finding suggests that service providers must attempt to improve their service quality, especially in their customers' eyes.

\section{References:}

1. Anderson, RE \& Srinivasan, SE 2003, 'E-Satisfaction and E-Loyalty: A Contingency Framework', Psychology \& Marketing, vol. 20, no. 2, February, pp. 123 - 38.

2. Anderson, E.W., Fornell, C. and Lehmann, D.R. (1994), "Customer satisfaction, market share, and profitability: findings from Sweden", Journal of Marketing, Vol. 58, July, pp. 53-66. 
3. AKEP, Electronic and Postal Communications Authority, Statistical Report 2016.

4. Athanassopoulos, AD \& Iliakopoulos, A 2003, 'Modeling Customer Satisfaction in Telecommunications: Assessing the Effects of Multiple Transaction Points on the Perceived Overall Performance of the Provider', Production and Operations Management, vol. 12, no. 2, pp. $224-45$.

5. Aydin, S \& Ozer, G 2005, 'The Analysis of Antecedents of Customer Loyalty in the Turkish Mobile Telecommunication Market', European Journal of Marketing, vol. 39, no.7/8, pp. 910 - 25.

6. Cronin, JJ \& Taylor, SA 1992, 'Measuring Service Quality: A Reexamination and Extension', Journal of Marketing, vol. 56, no. 3, July, pp. $55-68$.

7. Chun, R 2005, 'Corporate Reputation: Meaning and Measurement', International Journal of management Reviews, vol. 7, no. 2, pp. 91 109.

8. Chuang, S.-C., Cheng, Y.-H., Chang, C.-J. and Yang, S.-W. (2012), "The effect of service failure types and service recovery on customer satisfaction: A mental accounting perspective", The Service Industries Journal, Vol. 32, No. 2, pp. 257-271.

9. Darley, W.K., Blankson, C., \& Luethge, D.J. (2010). Toward an Integrated Framework for Online Consumer Behavior and Decision Making Process: A Review. Psychology \& Marketing, 27 (2), 94-116.

10. Elkins, E. (2018), "Powered by Netflix: Speed test services and videoon-demand's global development projects", Media, Culture \& Society, Vol. 40, No. 6, pp. 838-855.

11. Faulhaber, G.R. (2010), "Transparency and broadband Internet service providers", International Journal of Communication, Vol. 4, No 1, pp. 738-757.

12. Hu, AW \& Hwang, I 2006, 'Measuring the Effects of Consumer Switching Costs on Switching Intention in Taiwan Mobile Telecommunication Services', Journal of American Academy of Business, vol. 9, no. 1, March, pp. 75 - 85.

13. Ismail, H \& Khatibi, A 2004, 'Study of the Relationship Between Perception of Value and Price and Customer Satisfaction', Journal of American Academy of Business, vol. 4, no. 1/2, March, pp. 309 - 13.

14. ITU (2017), The state of broadband: Broadband catalyzing sustainable development, International Telecommunication Union: Genf. https://www.itu.int/dms BROADBAND.18-2017-PDF-E.pdf

15. Khatibi, AA, Ismail, S \& Thyagarajan, V 2002, 'What Drives Customer Loyalty: An Analysis from the Telecommunications Industry', Journal 
of Targeting, Measurement and Analysis for marketing, vol. 11, no. 1, September, pp. 34 - 44.

16. Kim, H \& Yoon, CH 2004, 'Determinants of Subscriber Churn and Customer Loyalty in the Korean Mobile Telephony Market', Telecommunications Policy, vol. 28, pp. 751 - 65.

17. Gerpott, T.J., Rams, W., and Schindler, A., (2001) - "Customer retention, loyalty, and satisfaction in the German mobile telecommunications market. Telecommunications Policy, Vol. 25, No. 4, pp. 249-269.

18. Giovanis, A.N., Zondiros, D. and Tomaras, P. (2014), “The antecedents of customer loyalty for broadband services: The role of service quality, emotional satisfaction and corporate image", Procedia Social and Behavioral Sciences, Vol. 148, pp. 236-244.

19. Grzybowski, L., Hasbi, M. and Liang, J. (2018), "Transition from copper to fiber broadband: The role of connection speed and switching costs", Information Economics and Policy, Vol. 42, No. 1, pp. 1-10.

24. Liu, Y., \& Jang, S. (2009). Perceptions Of Chinese Restaurants In The U.S.: What Affects Customer Satisfaction And Behavioral Intentions? International Journal of Hospitality Management, 28(3), 338-348.

25. Lee, H, Lee, Y \& Yoo, D 2000, 'The Determinants of Perceived Service Quality and Its Relationship with Satisfaction, Journal of Services Marketing, vol.14,no.3,pp.217-31.

26. Lee, J., Lee, J., \& Freick, L. (2001) - The impact of switching costs on the customer satisfaction-loyalty link: Mobile phone service in France. Journal of Services Marketing, 15(1), 35-48.

27. McColl-Kennedy, JR \& Fetter, J, R.E. 2001, 'Dimensions of Consumer Search Behavior in Services', The Journal of Services Marketing, vol. 13 , no. 3

28. Oliver, R.L. (1999) - "Whence customer loyalty?" Journal of Marketing, Vol. 63, pp. 33-44.

29. Parasuraman, A, Zeithaml, VA \& Berry, LL 1985, 'A Conceptual Model of Service Quality and Its Implications for Future Research, Journal of Marketing, vol.49, Fall, pp.41-50.

30. Parasuraman, A., Zeithaml, V., \& Berry, L. (1998). SERVQUAL: A Multiple-item Scale for Measuring Consumer Perceptions of Service Quality. Journal of Retailing, 64(1), 12-37.

31. Ranaweera, C \& Prabhu, J 2003, 'The Influence of Satisfaction, Trust and Switching Barriers on Customer Retention in a Continuous Purchasing Setting', International Journal of Service Industry Management, vol. 14, no. 4, pp. 374 - 95.

32. Sekaran, U 2003, Research Method for Business: A Skill Building Approach, 4th edn, John Wiley \& Sons, Inc. , New York. 
33. Sekaran, U. and Bougie, R. (2009): "Research Methods for Business", John Wiley and Sons, 5th Edition, USA.

34. Stocker, V. and Whalley, J. (2018), "Speed isn't everything: A multicriteria analysis of the broadband consumer experience in the UK", Telecommunications Policy, Vol. 42, No. 1, pp. 1-14.

35. Yi, Y \& La, S 2004, 'What Influences the Relationship Between Customer Satisfaction and Repurchase Intention? Investigating the Effects of Adjusted Expectations and Customer Loyalty', Psychology \& Marketing, vol. 21, no. 5, May, pp. 351 - 73.

36. Wang, Y, Lo, H \& Yang, Y 2004, 'An Integrated Framework for Service Quality, Customer Value, Satisfaction: Evidence from China's Telecommunication Industry', Information Systems Frontiers, vol. 6, no. 4 